\title{
Association of Socio-Economic, Communication, Psychological Attributes of SHC Beneficiaries with their Impact Level in terms of Soybean Production in Ujjain Block of Ujjain District, M.P, India
}

\author{
Poonam Chakrawarty ${ }^{1 *}$, Sandhya Choudhary ${ }^{2}$, Abhay Wankhede ${ }^{2}$ and S. K. Jain ${ }^{3}$ \\ ${ }^{1}$ Jawaharlal Nehru Krishi Vishwa Vidyalaya, Jabalpur-482002, M.P, India \\ ${ }^{2}$ Extension Education, College of Agriculture, Indore, India \\ ${ }^{3}$ Department of Agricultural Economics, College of Agriculture, Indore, India \\ *Corresponding author
}

\section{A B S T R A C T}

Keywords

Soil Health Card (SHC), Soybean Production,

Soybean bowl of India

Article Info

Accepted:

12 November 2019

Available Online:

10 December 2019
Soil is one of the elements required for farming as it provides nutrients to the plants. Healthy soil containing all the elements for growth and development of crop and on the other hand soil deprived of one or more elements either reduces production or degrades quality of crops. Proportion and quantity of macro and micro nutrients refers to the soil health. As far as agriculture production is concerned, soil health plays a vital role in ensuring sustainable production with optimizing the utilization of fertilizers and reducing its wastage. To avoid deterioration of soil in long run and visualizing the importance of balance nutrient in crop production. Soil Health Card (SHC) is a scheme launched by the Government of India in February 2015 in Gujarat. The government plans to issue soil cards to farmers which will carry crop-wise recommendations of nutrients and fertilizers required for the individual farms to help farmers to improve productivity through judicious use of inputs. Madhya Pradesh is known as the Soybean bowl of India.

\section{Introduction}

Soil Health Card (SHC) is a Government of India's scheme promoted by the Department of Agriculture \& Co-operation under the Ministry of Agriculture and Farmers' Welfare. It is being implemented through the
Department of Agriculture of all the State and Union Territory Governments. A SHC is meant to give each farmer soil nutrient status of his/her holding and advice him/her on the dosage of fertilizers and also the needed soil amendments, that s/he should apply to maintain soil health in the long run.SHC is a 
printed report that a farmer will be handed over for each of his holdings. It will contain the status of his soil with respect to 12 parameters, namely N, P, K (Macro-nutrients); $\mathrm{S}$ (Secondary- nutrient); $\mathrm{Zn}, \mathrm{Fe}, \mathrm{Cu}, \mathrm{Mn}, \mathrm{Bo}$ (Micro - nutrients); and pH, EC, OC (Physical parameters). Based on this, the SHC will also indicate fertilizer recommendations and soil amendment required for the farm. It will be made available once in a cycle of 3 years, which will indicate the status of soil health of a farmer's holding for that particular period.

Soybean is known as "golden bean", "miracle crop" etc, because of its several uses, It is an excellent source of protein and oil. It contains good quality protein (43\%), carbohydrate $(21 \%)$, mineral (5\%), moisture $(8 \%)$, fat $(20 \%)$, fiber $(4 \%)$ and reasonable amounts of vitamins. Soybean is one of the important crops of the world. Soybean has tremendous potential to meet the protein - calorie malnutrition of the ever increasing India population. Soya based food products are also suitable to diabetic patients as they contain less carbohydrates and low cholesterol. Soya protein is also good to people who are allergic to animal protein. Therefore, it is one of the most economical protein sources in the world. It is a versatile crop with innumerable possibilities of improving agriculture and supporting industry (Ali, 2003). Production of soybean in India at the present time is restricted mainly to Madhya Pradesh, Uttar Pradesh, Maharashtra and Gujarat. Soybean the number one oilseed crop in the world has recently occupied an important place in the edible oil and agriculture economy of the country.Its inclusion in the cropping system of the country in general and in the states of M.P., Maharashtra and Rajasthan particular has resulted in improvement of socioeconomic status of farmers. Madhya Pradesh is known as the Soybean bowl of India, because major chunk of Soybean production is contributed by Madhya Pradesh State alone.
Madhya Pradesh is having presently 22 Soil Testing Labs and Soil Surveyors. Present study was based on primary and secondary data.

The main objectives of this study includes Association of Socio-economic, communication, psychological attributes of SHC beneficiaries with their impact level in terms of Soybean production in Ujjain block of Ujjain District, M.P, India.

Asane (2003) found that annual income of soybean growers was significantly related with adoption of cultivation practices.

Sharma et al., (2005) reported that the age had positive and highly significant relation with the adoption.

Khatarker (2005) reported that education was significantly related with the adoption of soybean technology.

Sharma (2007) found that mass media exposure had significant correlation with extent of adoption of soybean production technology.

Patidar (2007) reported that economic motivation of sesame oilseed crop growers showed highly significant positive relationship with adoption level.

\section{Materials and Methods}

In this study multistage testing procedure has been adopted. Ujjain area has six blocks. All the six block of the locale have the SHC holders for Soybean production out of which one block for example Ujjain has been taken because of higher number of SHC holders in that block. Ujjain block contains twenty five villages out of which four villages have been chosen by the SHC Center for improved development practices 
of Soybean production. A rundown of 300 SHC holders (2015-16) of the chose four villages has been gotten from KVK, Ujjain and 120 farmers have been chosen haphazardly for present investigation

\section{Results and Discussion}

In order to study the association as influencing factors like socio economic, communication and psychological attributes of SHC beneficiaries and their impact in soybean production, the values of $\chi^{2}$ were calculated for individual independent variable in relation to dependent variable as follows.

The table 1 describes the association of socioeconomic, communication, psychological attributes of SHC beneficiaries with their impact level in terms of Soybean production and its results are discussed as follows:

\section{Association between age of SHC beneficiaries and their Impact level}

The chi-square value 21.2643 at 5 percent level with 4 d.f. was found to be significant. Hence, the conclusion can be drawn that there was significant association between age of the SHC beneficiaries and their Impact level of Soybean production technology.

\section{Association between education level of SHC beneficiaries and their Impact level}

The calculated Chi-square value 18.1361 at 5 percent level with 4 d.f. was found to be significant.

Hence, the conclusion can be drawn that there was significant association between education level of the SHC beneficiaries and their Impact level of Soybean production technology.
Association between income of SHC beneficiaries and their Impact level

The calculated Chi-square value 19.7426 at 5 percent level with 4 d.f. was found to be significant. Hence, the conclusion can be drawn that there was significant association between income from soybean of the SHC beneficiaries and their Impact level of Soybean production technology.

\section{Association between farm size of SHC beneficiaries and their Impact level}

The calculated Chi-square value 20.414 at 5 percent level with 4 d.f. was found to be significant. Hence, the conclusion can be drawn that there was significant association between farm size from soybean of the SHC beneficiaries and their Impact level of of Soybean production technology.

Association between source of irrigation and Impact level of SHC beneficiaries

The calculated Chi-square value 22.464 at 5 percent level with 4 d.f. was found to be significant. Hence, the conclusion can be drawn that there was significant association between source of irrigation of the beneficiaries and their Impact level of soybean production technology.

Association between farm mechanization and Impact level of SHC beneficiaries

The calculated Chi-square value 15.6802 at 5 percent level with 4 d.f. was found to be significant. Hence, the conclusion can be drawn that there was significant association between farm mechanization of the beneficiaries and their Impact level of soybean production technology. 
Table.1 Association of Socio-economic, communication, psychological attributes of SHC beneficiaries with their impact level in terms of Soybean production

\begin{tabular}{|c|c|c|c|}
\hline S. No. & Variable & $\chi^{2}$ value & Association with impact \\
\hline $\mathbf{1 .}$ & Age & $21.2643^{*}$ & S. \\
\hline $\mathbf{2 .}$ & Education & $18.1361^{*}$ & $\mathrm{~S}$. \\
\hline $\mathbf{3 .}$ & Annual income & $19.7624^{*}$ & $\mathrm{~S}$. \\
\hline $\mathbf{4 .}$ & Farm size (under soybean) & $20.4140^{*}$ & $\mathrm{~S}$. \\
\hline $\mathbf{5 .}$ & Source of irrigation & $22.4640^{*}$ & $\mathrm{~S}$. \\
\hline $\mathbf{6 .}$ & Farm mechanization & $15.6802^{*}$ & $\mathrm{~S}$. \\
\hline $\mathbf{7 .}$ & Information seeking behaviour & $16.9580^{*}$ & $\mathrm{~S}$. \\
\hline $\mathbf{8 .}$ & Economic motivation & $11.9930^{*}$ & $\mathrm{~S}$. \\
\hline $\mathbf{9 .}$ & Risk bearing ability & $16.1940^{*}$ & $\mathrm{~S}$. \\
\hline
\end{tabular}

4 d.f. $=$ degree of freedom, N.S. $=$ Non- significant, S. $=$ Significant, $*$ = significant at 0.05 level

Association between Information seeking behavior and Impact level of SHC beneficiaries

The calculated Chi-square value 16.958 at 5 percent level with 4 d.f. was found to be significant. Hence, the conclusion can be drawn that there was significant association between information seeking behavior of the beneficiaries and their Impact level of soybean production technology.

Association between economic motivation and Impact level of SHC beneficiaries

The calculated Chi-square value 11.993 at 5 percent level with 4 d.f. was found to be significant. Hence, the conclusion can be drawn that there was significant association between economic motivation of the beneficiaries and their Impact level of soybean production technology.

\section{Association between risk bearing ability and Impact level of SHC beneficiaries}

The calculated Chi-square value 16.194 at 5 percent level with 4 d.f. was found to be significant. Hence, the conclusion can be drawn that there was significant association between risk bearing ability of the beneficiaries and their Impact level of soybean production technology.

\section{References}

Arya, R.L., Arya, Sonam, Kurel, R.S. (2012) Indira Agriculture Competition Explorer, P.N.365.

Chaudhari, M.B. (2009). Technological gap in cotton cultivation among the farmers of Vadodara district of Gujarat state. M.Sc. (Agri.) Thesis (unpublished), AAU, Anand.

Kerlinger, F. N. (1976). Foundation of behavioural research, Surjee Publication, New Delhi. Pp. 198-204.

Sharma, A., M.K. Khore and L.N. Sharma (2005) Adoption of farm and home innovation by tribal farm woman. Madhya.. Ext. Edu., 8(1): 1-3.

Sharma, V.K.; Singh, D.P. and S. Tomar (2007). Perception of borrower farmers towards Kisan Credit Card Scheme. Fourth National Extn. Edu. Congress. Pp 109-110.

Singh,A.K. (2009). A study on impact of oilseed Front Line Demonstrations in adoption of production technology by farmers in Tikamgarh District (MP). M.Sc. (Ag.) thesis, J.N.K.V.V., Jabalpur. 


\section{How to cite this article:}

Poonam Chakrawarty, Sandhya Choudhary, Abhay Wankhede and Jain, S. K. 2019. Association of Socio-Economic, Communication, Psychological Attributes of SHC Beneficiaries with their Impact Level in terms of Soybean Production in Ujjain Block of Ujjain District, M.P, India. Int.J.Curr.Microbiol.App.Sci. 8(12): 1297-1301. doi: https://doi.org/10.20546/ijcmas.2019.812.158 